\title{
Vulkansk aktivitet \\ - første halvdel af 2009
}

Af geolog Susanne Plesner, GeologiskNyt

I det forgange halvår kan vi konstatere de største forskelle fra sidste halvår af 2008 i Stillehavsregionen. Filippinerne var godt repræsenteret sidste gang, men der har ikke været noget bemærkelsesværdigt fra dem de seneste seks måneder.

Derimod er Vanuatu, Tonga og Marianer Øerne kommet godt med, herunder en undersøisk vulkan ved sidstnævnte. Se senere.

Kun en enkelt vulkan i Afrika synes at holde sig i gang, og der synes også at være faldet ro på Mt. St. Helens i staten Washington, USA, for en stund. Kilauea på Hawaii og Etna på Sicilien er mere eller mindre i gang hele tiden, som vi har set det gennem de sidste mange år.

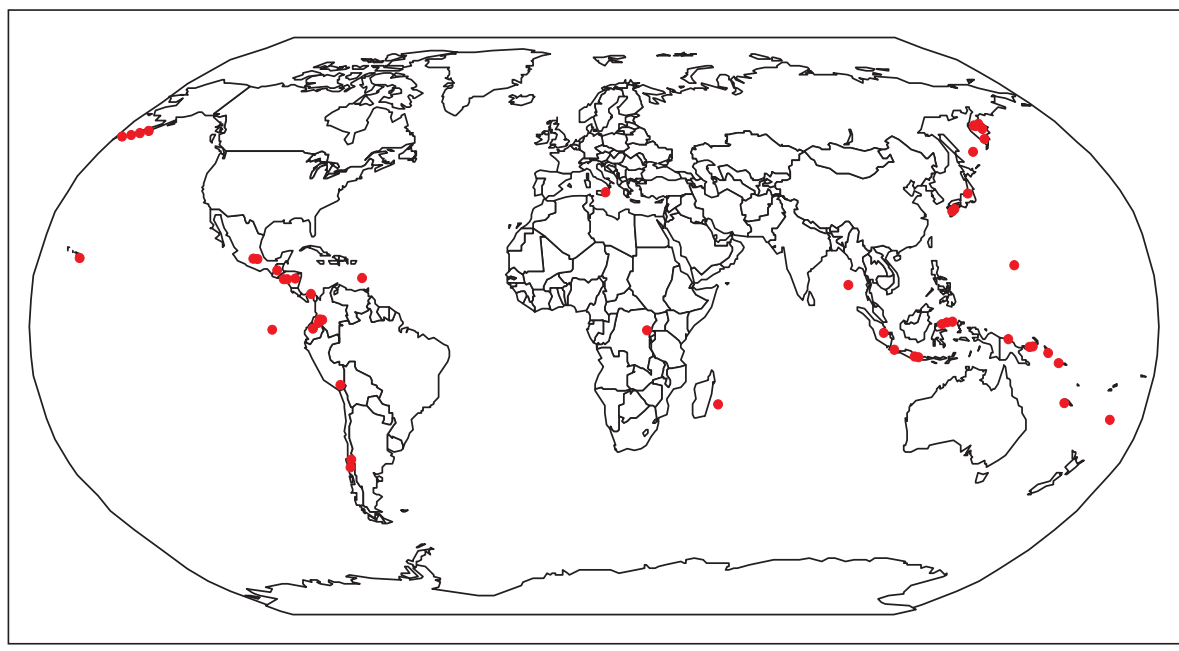

Verdenskort, den med røde fyldte cirkler viser fordelingen af den vulkanske aktivitet de seneste seks måneder. (Grafik: Forfatteren)

NW Rota-1

Den submarine vulkan NW Rota-1 ud for
Marianer Øerne blev opdaget første gang i 2003. Der har for nylig været endnu en

\section{Vulkansk aktivitet de sidste 6 måneder}

\section{Nordlige Stillehavsregion}

Kilauea, Hawaii, USA

Redoubt, Alaska USA

Shishaldin, Aleuterne, USA

Okmok, Aleuterne, USA

Veniaminof, Alaska, USA

NW Rota-1, Mariana Islands

Pagan, Mariana Island

Suwanose-Jima, Ryukyu Øerne, Japan

Sakura-Jima, Kyushu, Japan

Mijake-Jima, Japan,

Asama, Japan

Kushinoerabu-Jima, Japan

Ebeko, Paramushir Island

Karangetang, Indonesien

Gamkonora, Indonesien

Dukono, Indonesien

\section{Sydlige Stillehavsregion}

Semeru, Java, Indonesien

Batu Tara, Indonesien

Krakatau, Indonesien

Lewotobi, Indonesien

Dieng volcanic complex, Java, Indonesien

Dempo, Sumatra, Indonesien

Rinjani, Indonesien
Ambrym, Vanuatu

Yasur, Vanuatu

Bagana, Papua Ny Guinea

Rabaul, Papua Ny Guinea

Manam, Papua Ny Guinea

Ulawun, New Britain

Hunga Tonga-Hunga Ha'apai, Tonga

West Mata, Tonga

Mellemamerika, Mexico og Vestindien

Masaya, Nicaragua

Arenal, Costa Rica

Poas, Costa Rica

Colima, Mexico

Popocatépetl, Mexico

Fuego, Guatemala

Santa María, Guatemala

Pacaya, Guatamala 14,38N 90,60W

Soufriere Hills, Montserrat

San Cristobal, Nicaragua

\section{Sydamerika}

Tungurahua, Ecuador

Reventador, Ecuador

Sangay, Ecuador

Guagua Pichincha, Ecuador
Fernandina, Galapagos

Galeras, Colombia

Nevado del Huila, Colombia

Llaima, Chile

Chaiten, Chile

Ubinas, Peru

Callaqui, Chile

\section{Rusland}

Karymsky, Kamchatka

Shiveluch, Kamchatka

Benzymianny, Kamchatka

Kliuchevskoi, Kamchatka

Koryaksky, Kamchatka

Gorely, Kamchatka

Sarychev Peak, Matua Island

\section{Afrika \& Mellemøsten}

Nyiragongo, Demokratiske Republik Congo

\section{Indiske ocean}

Piton de la Fournaise 21S, 55E

Barran Island, Indien

Europa

Etna, Italien 


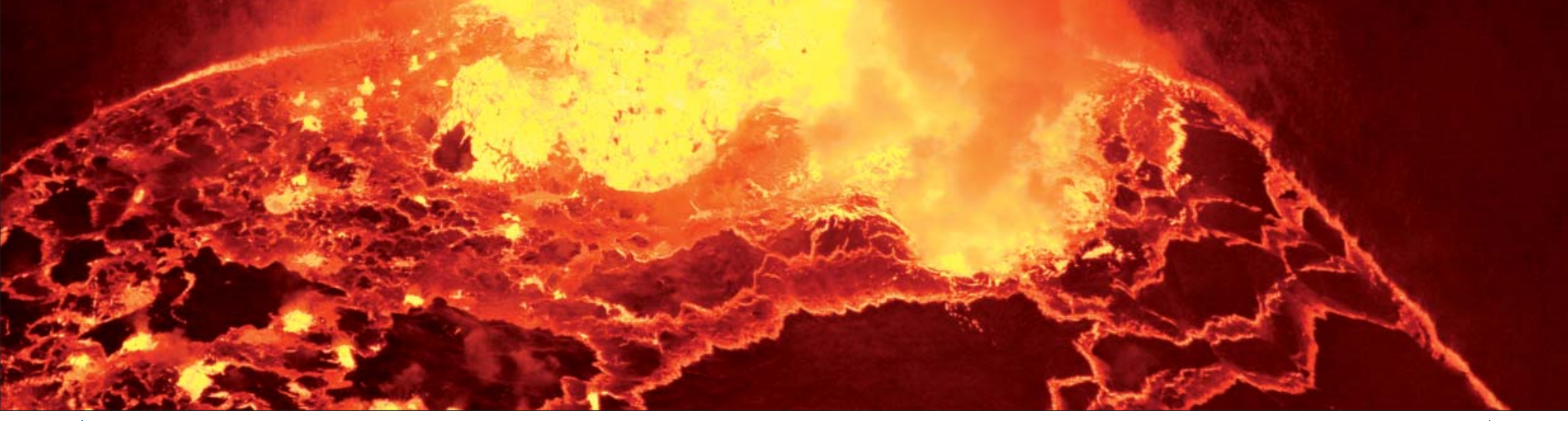

Vulkanen Nyiragongo beliggende i Demokratiske Republik Congo i udbrud. Billedet stammer fra et udbrud i juli 2006. (Foto: Tom Pfeiffer)

ekspedition til vulkanen, hvor forskerne kan konstatere, at den kontinuerligt er i udbrud, hvilket ikke engang er særligt almindeligt for vulkaner på land.

Den er desuden unik, fordi man her, som det eneste sted på Jorden, har været i stand til at observere aktiv dybhavsvulkanisme direkte. Man har derfor her et fantastisk undersøisk laboratorium, hvor man kan lære direkte om, hvordan undersøiske udbrud foregår, hvordan vulkanerne vokser, og ikke mindst hvordan den vulkanske aktivitet påvirker havmiljøet både i umiddelbar nærhed og lidt længere væk fra udbrudsstedet.

Det er muligt for forskerne at komme helt tæt på udbrudsområdet og observere, hvad der sker her. Dette er muligt på grund af trykket fra de overliggende vandmasser, der undertrykker de ellers så voldsomme kræfter, der normalt er forbundet med vulkanudbrud på land.

Siden det sidste besøg i 2006 er vulkanen vokset betragteligt med en vulkankegle, som, bathymetriske målinger viser, er så høj som en 10 etagers bygning. Udbrudsområdet befinder sig nu i toppen af denne. Siden
2006 har et nyt økosystem også udviklet sig i området, som ser ud til at trives godt.

For yderligere information kan jeg anbefale linket nedenfor. Her findes billeder og videoklip fra ekspeditionerne.

\section{Relevante links:}

http://www.volcano.si.edu/reports/usgs/index.cfm?content $=$ archive

http://volcano.und.nodak.edu/ http://nwrota2009.blogspot.com/

\section{Kort nyt}

\section{Russisk dominans på energiområdet} Den arktiske undergrund rummer ifølge U.S. Geological Survey op mod $30 \%$ af Verdens uudnyttede naturgasreserver og hen ved $13 \%$ af de uudnyttede olieforekomster. U.S. Geological Survey har undersøgt forholdene indgående, og resultaterne er netop blevet offentliggjort i det amerikanske videnskabelige tidsskrift Science Magazine.

Den russiske interesse for at få kontrol over det meste af det arktiske område skal ses i det lys. Efter de seneste års afsmeltning af Nordpolens ismasser om sommeren er regionens attraktivitet for de energiproducerende lande øget. Ydermere ligger energireserverne på mindre end 500 meters vanddybde, hvilket gør efterforskning og boring relativt let.

Der er dog en FN-konvention, der foreskriver, at de enkelte lande kun har krav på havbundens ressourcer i en udstrækning på 200 miles (ca. $330 \mathrm{~km}$ ) fra de respektive landes kystlinjer.

$J P / S L J$

\section{Isfjeld river sig løs}

Et isfjeld på $160 \mathrm{~km}^{2}$ er ved at rive sig løs fra indlandsisen i Nordgrønland. Isfjeldet stammer fra Petermann Gletscheren, der ligger over for den canadiske ø Ellesmere Island. Canadas tjeneste for isovervågning, Canadian Ice Service, har meddelt, at der er opstået en sprække i gletsjeren på $1 \mathrm{~km}$ i bredden og $12 \mathrm{~km}$ i længden. Ifølge canadiske glaciologer vil isbjerget formodentlig rive sig løs, næste gang isen rykker sig.

Ritzau/SLJ

\section{Jordskælv ud for Mindanao}

Et jordskælv med en styrke på 6,3 på richterskalaen blev d. 14. juni registreret i havet ud for den filippinske ø Mindanao, rapporterede USA's Geologiske Undersøgelser. Skælvets epicenter lå $159 \mathrm{~km}$ østsydøst for byen General Santos. De filippinske myndigheder har ikke meldt om tilskadekomne eller materielle skader.

Reuters/SLJ 